\title{
Respiration rate of adult pilchard Sardinops sagax in relation to temperature, voluntary swimming speed and feeding behaviour
}

\author{
C. D. van der Lingen* \\ Sea Fisheries Research Institute, Private Bag X2, Roggebaai 8012, South Africa
}

\begin{abstract}
Laboratory experiments investigated the effect of temperature, voluntary swimming speed and feeding behaviour on the respiration rate of adult pilchard Sardinops sagax. Mean routine respiration was $0.178 \pm 0.055 \mathrm{mg} \mathrm{O}_{2} \mathrm{~g}^{-1}$ wet wt $\mathrm{h}^{-1}$ Respiration rate increased exponentially with temperature, and the mean $Q_{10}$ over the temperature range 10 to $22^{\circ} \mathrm{C}$ was $1.82 \pm 0.35$. Significant linear relationships were established between respiration rate and voluntary swimming speed for non-feeding, filter-feeding and particulate-feeding activities. Particulate-feeding was the most energetically expensive activity state. Swimming speed was the primary determinant of respiration rate when filterfeeding, whereas swimming speed and feeding intensity were equally important in determining respiration rate when particulate-feeding. That filter-feeding is energetically cheaper than particulate-feeding for this species supports previous work suggesting that pilchard is primarily a filter-feeder. Results presented here contrast with those for Cape anchovy Engraulis capensis, a species for which filterfeeding is energetically more expensive than particulate-feeding. Possible reasons for this difference are discussed. Calculation of a mean $R Q$ (respiratory quotient) of $0.955 \pm 0.099$ for pilchard indicates that this species catabolises both protein and carbohydrate.
\end{abstract}

KEY WORDS: Sardinops sagax Planktivorous fish $\cdot$ Respiration rate $\cdot$ Feeding behaviour $\cdot Q_{10} \cdot R Q$

\section{INTRODUCTION}

Catches by the pelagic fishery in the Benguela Current ecosystem are dominated by 3 clupeoid species: pilchard Sardinops sagax, anchovy Engraulis capensis and round herring Etrumeus whiteheadi (Crawford et al. 1987, Armstrong \& Thomas 1989). Although all 3 species are planktivorous, each consumes different plankton fractions. Pilchard feed primarily upon phytoplankton (Davies 1957, King \& Macleod 1976) and microzooplankton (van der Lingen 1994) and are essentially nonselective filter-feeders (van der Lingen 1994). Anchovy are predominantly particulate-feeders (James \& Findlay 1989), with mesozooplankton such as copepods and euphausiids comprising their major dietary component (James 1987). Round herring feed exclusively on zooplankton (Wallace-Fincham 1987), presumably through particulate-feeding only (James 1988).

•E-mail:vdlingen@sp.sfri.ac.za
The trophodynamics of Engraulis capensis are well documented (James 1987, James \& Findlay 1989, James \& Probyn 1989, James et al. 1989b), and carbon and nitrogen budgets for this species have been constructed (James et al. 1989a). The calculated maintenance ration derived from these budgets has been compared with yearly estimates of mesozooplankton biomass and production on fish spawning grounds during the peak spawning period in order to assess the probability of successful spawning by anchovy in a potentially food-limiting environment (Peterson et al. 1992). Such predictions of spawning success can provide valuable information for the management of this commercially important, recruit-based fishery. Construction of an energy budget for pilchard requires that similar information be collected for this species.

The present study was undertaken to investigate the relationship between voluntary swimming speeds and oxygen consumption rates of pilchard during several 
activity states, namely non-feeding, filter-feeding and particulate-feeding, and to determine whether this relationship was significantly different for each activity state. Additionally, the influence of temperature upon oxygen consumption rates was examined, and data were collected for calculation of a respiratory quotient $(R Q)$ for this species.

The experimental approach reported here closely follows that used by James \& Probyn (1989) to determine the relationship between respiration rate, swimming speed and feeding behaviour for Engraulis capensis. This common approach enables a detailed comparison of the metabolic costs associated with various feeding strategies employed by these co-occurring planktivorous clupeoids and may permit a better understanding of the trophic interactions between this species pair. Such understanding may also provide some insights into the 'regime-problem' - worldwide large-scale fluctuations in sardine (pilchard) and anchovy populations, with anchovy often abundant when sardine are scarce and vice versa (Lluch-Belda et al. 1989, 1992).

\section{MATERIALS AND METHODS}

Pilchard used for oxygen consumption rate experiments were collected and maintained as described by van der Lingen (1994). Nineteen experiments (Table 1) were conducted using a school of 10 adult fish (256.0 \pm $9.8 \mathrm{~mm}$ total length, $\mathrm{TL}_{;} 146.4 \pm 15.3 \mathrm{~g}$ wet $\mathrm{wt}$ ) maintained in a $2.0 \mathrm{~m}$ diameter, $3000 \mathrm{l}$ fibreglass pool subject to the ambient light regime. Fish were starved for periods of 1 to $6 \mathrm{~d}$ prior to experimentation in order to permit evacuation of the gastrointestinal tract and ensure that the last meal had no effect on the metabolism of the fish during experimentation. Two control experiments, without fish in the sealed respirometer, were also conducted.

Of the 19 experiments performed, 12 were conducted at ambient $\left(14.9\right.$ to $\left.18.3^{\circ} \mathrm{C}\right), 4$ at lower, and 3 at higher temperatures (Table 1). The experimental temperatures used encompass the range observed in the southern Benguela, where sea surface temperature shows seasonal variation from 10 to $22^{\circ} \mathrm{C}$ (Shelton \& Hutchings 1990). When temperatures other than ambi-

Table 1. Summary of experiments performed. Pu: pulsed [single or double ( $\times 2)$ ] addition of food; Co: continuous addition of food; -Samples collected for respiratory quotient $(R Q)$ determination; BW: body weight $F$ F: filter-feeding; P: particulate-feeding. Composition of wild phytoplankton: (1) $80 \mathrm{l}$ of collected phytoplankton concentrated to $5 \mathrm{l}$ on a $37 \mu \mathrm{m}$ mesh and added for each pulse; consisted of $43,23,16$ and $13 \%$ Chaetoceros spp., Thalassiosira spp., Nitzschia spp. and Skeletonema costatum by number respectively. (2) $160 \mathrm{l}$ of collected phytoplankton concentrated to $10 \mathrm{l}$ on a $37 \mu \mathrm{m}$ mesh; consisted of 47 and $22 \%$ Chaetoceros spp. and $S$. costatum by number respectively. (3) $130 \mathrm{l}$ of collected phytoplankton concentrated to $15 \mathrm{lon}$ a $37 \mu \mathrm{m}$ mesh; consisted of 40 and $19 \%$ S. costatum and Nitzschia spp. by number respectively. Composition of wild zooplankton: (4) Zooplankton passed through $500 \mu \mathrm{m}$ mesh and retained on a $100 \mu \mathrm{m}$ mesh, consisted of 25,18 and $1.5 \%$ Oithona spp., copepod eggs, and copepod nauplii by number respectively. (5) Zooplankton retained on a $500 \mu \mathrm{m}$ mesh; consisted of 64,17 and $16 \%$ Acartia africana, Oithona spp. and 'small calanoid copepods' (Clausocalanus spp., Paracalanus spp. and Ctenocalanus spp.) by number respectively. (6) Zooplankton retained on a $500 \mu \mathrm{m}$ mesh; consisted of 61,19 and $13 \% A$. africana, Centrophages brachiatus and Oithona spp. by number respectively. (7) Zooplankton retained on a $950 \mu \mathrm{m}$ mesh; consisted of 61,22 and $12 \%$ Calanoides carinatus, Oithona spp. and C. brachiatus by number respectively

\begin{tabular}{|c|c|c|c|c|c|c|c|}
\hline Expt & $\begin{array}{c}\text { Initial } \\
\text { temp. }\left({ }^{\circ} \mathrm{C}\right)\end{array}$ & $\begin{array}{l}\text { Starvation } \\
\text { time (d) }\end{array}$ & Food organism & $\begin{array}{l}\text { Food size } \\
(\mathrm{mm})\end{array}$ & $\begin{array}{c}\text { Food } \\
\text { addition }\end{array}$ & $\begin{array}{c}\text { Ration } \\
(\% \text { wet } \mathrm{BW})\end{array}$ & $\begin{array}{l}\text { Feeding } \\
\text { response }\end{array}$ \\
\hline 1 & 16.0 & 6 & Wild phytoplankton (1) & $0.02 \pm 0.02$ & $\mathrm{Pu}(\times 2)$ & 0.55 & $F$ \\
\hline 2 & 16.7 & 1 & Wild phytoplankton (2) & $0.01 \pm 0.02$ & $\mathrm{Pu}$ & 1.42 & $\mathrm{~F}$ \\
\hline 3 & 14.9 & 1 & Wild phytoplankton (3) & $0.01 \pm 0.02$ & $\mathrm{Pu}$ & 0.19 & $\mathrm{~F}$ \\
\hline 4 & 14.9 & 4 & Artemia nauplii & $0.57 \pm 0.12$ & $\mathrm{Pu}(\times 2)$ & 2.63 & $\mathrm{~F}$ \\
\hline 5 & 16.7 & 2 & Artemia juveniles & $3.90 \pm 1.56$ & $\mathrm{Pu}(\times 2)$ & 1.69 & $\mathrm{~F}$ \\
\hline 6 & 16.4 & 3 & - & & & & \\
\hline 7 & 17.4 & 2 & - & & & & \\
\hline $8^{\circ}$ & 16.3 & 5 & Mysids (Gastrosaccus) & $11.68 \pm 2.83$ & $\mathrm{Pu}$ & 0.65 & $\mathrm{P}$ \\
\hline $9 \cdot$ & 19.0 & 5 & Artemia adults & $5.44 \pm 2.58$ & $\mathrm{Pu} / \mathrm{Co}$ & 2.02 & $\mathrm{P}$ \\
\hline $10^{\circ}$ & 20.1 & 2 & Artemia juveniles & $4.76 \pm 1.17$ & $\mathrm{Co}$ & 2.14 & $\mathrm{P}$ \\
\hline 11 & 11.9 & 4 & Artemia nauplu & $0.51 \pm 0.07$ & $\mathrm{Co}$ & 0.54 & $\mathrm{~F}$ \\
\hline $12^{\circ}$ & 10.0 & 1 & - & & & & \\
\hline 13 & 9.7 & 4 & Artemia nauplii & $0.58 \pm 0.07$ & $\mathrm{Co}$ & 0.62 & F \\
\hline 14 & 12.6 & 2 & - & & & & \\
\hline 15 & 22.7 & 3 & Artemia nauplii & $0.58 \pm 0.10$ & $\mathrm{Co}$ & 0.49 & $\mathrm{~F}$ \\
\hline 16 & 18.3 & 1 & Wild zooplankton (4) & $0.51 \pm 0.23$ & $\mathrm{Co}$ & 1.63 & F \\
\hline 17 & 16.0 & 5 & Wild zooplankton (5) & $0.88 \pm 0.24$ & $\mathrm{Pu}(\times 2)$ & 0.53 & $F$ \\
\hline 18 & 16.5 & 2 & Wild zooplankton (6) & $1.23 \pm 0.29$ & $\mathrm{Pu}$ & 0.34 & F \\
\hline 19 & 16.1 & 2 & Wild zooplankton (7) & $1.75 \pm 0.95$ & Co & 1.86 & $P$ \\
\hline
\end{tabular}


ent were required, the experimental tank was connected to a temperature-controlled $800 \mathrm{l}$ reservoir via a submersible pump and an overflow system. Temperatures were raised or lowered from ambient to the required level over a period of 2 to $3 \mathrm{~d}$ to allow for gradual thermal acclimation of the fish. Experiments at non-ambient temperatures were only initiated after the tank had been maintained at the required temperature for at least $4 \mathrm{~d}$.

Prior to experimentation, the tank was thoroughly cleaned and the water volume reduced to $1000 \mathrm{l}$, resulting in a water depth of $30 \mathrm{~cm}$. A transparent polycarbonate lid, which rested on a flange around the inside perimeter of the tank, was then lowered onto the water surface. The lid was held in position by a $40 \mathrm{~kg}$ circular steel bar lowered onto its periphery, which ensured that an airtight seal was formed between the tank walls, flange and lid. This effectively produced a closed-system respirometer. The polycarbonate lid was fitted with several sealable ports for positioning dissolved oxygen and temperature probes, obtaining water samples, and adding food. The fish were left undisturbed for $30 \mathrm{~min}$ after fitting of the polycarbonate lid, thereby allowing them sufficient time to resume normal behaviour.

Each experiment consisted of regular measurements of oxygen concentration in the water and appraisal of concomitant swimming speeds and feeding behaviour of the fish. Respiration rates for each sampling period were calculated using the following formula:

$$
\underset{\left(m g \mathrm{O}_{2} \mathrm{~g}^{-1} \text { wet } w \mathrm{w} \mathrm{h}^{-1}\right)}{\text { Respiration rate }}=\frac{\left(D O_{i}-D O_{f}\right) \times V}{(t / 60) \times W}
$$

where $D O_{i}$ and $D O_{f}$ are dissolved oxygen concentrations at time $i$ and time $f$ respectively $\left(\mathrm{mg} \mathrm{O}_{2} \mathrm{l}^{-1}\right), V$ is the water volume in the tank $(=10001), t$ is the interval between time $i$ and time $f$ (min), and $W$ is the total wet weight of all fish in the tank $(\mathrm{g})$.

Dissolved oxygen concentration was measured using a calibrated Hanna HI 9143 dissolved oxygen meter (Hanna Instruments) with a resolution of $0.01 \mathrm{mg} \mathrm{O}_{2}$ $1^{-1}$. Calibration was achieved using a modified Winkler technique (Williams \& Jenkinson 1982, Oudot et al. 1988). The dissolved oxygen probe was mounted in one of the sealable ports of the polycarbonate lid and projected $8 \mathrm{~cm}$ into the water below the level of the lid. A submersible water pump was positioned directly underneath the oxygen probe, providing sufficient water movement to ensure that the oxygen-depleted membrane surface was constantly replenished. In order to avoid generating water currents within the tank, the submersible pump was only activated $3 \mathrm{~min}$ prior to recording dissolved oxygen levels and switched off immediately thereafter. Activation of the pump had no apparent effect on fish swimming behaviour. Temperature was recorded with a digital readout thermometer, the probe of which was also mounted in the polycarbonate lid.

Fish swimming speed and feeding behaviour were monitored with a video camera mounted $2.5 \mathrm{~m}$ above the tank and recording at 25 frames $\mathrm{s}^{-1}$. Since swimming speed was monitored using a single camera, measurements were only valid for 2 dimensions. This measurement technique was considered legitimate, however, since fish movement in the 3rd dimension (vertical plane) was minimal as a result of the reduced water volume and shallow depth. The floor of the tank was marked with a reference grid of lines $10 \mathrm{~cm}$ apart. The fish were recorded for a $10 \mathrm{~min}$ period midway between each dissolved oxygen sampling time. Each video sequence was analysed to determine swimming speed and feeding intensity (\% of the school feeding) when the fish were feeding. Swimming speed was determined by counting the number of frames taken by individual fish to completely cross 1 of the grid lines, and was expressed as body lengths (BL) $\mathrm{s}^{-1}$. Thirty measurements of swimming speed were taken in each video sequence; only fish whose path did not deviate by more than approximately $20^{\circ}$ from their original heading during the counting period were considered. Feeding intensity was determined by measuring the proportion of the school feeding in a single randomly chosen frame when all 10 fish were clearly observable, and was repeated 50 times for each video sequence. Means and standard deviations for swimming speed and feeding intensity (where applicable) within each experiment were calculated for all time intervals. Differences between the variables measured during the course of an experiment were determined by ANOVA/Tukey multiple range analysis, with statistical significance being accepted at the $p<0.05$ level.

Once the polycarbonate lid was fitted and the fish had resumed normal behaviour, measurements of oxygen concentration and swimming speed were taken for 2 to $4 \mathrm{~h}$ before food was added. Dissolved oxygen and temperature readings were taken 30 min after placement of the lid, and every $30 \mathrm{~min}$ thereafter. Food particles were added to the tank after the non-feeding period, and oxygen concentration, swimming speed and feeding intensity were measured.

Food organisms (Table 1) were concentrated before being added to the tank. Food was added via a sealable port in the middle of the polycarbonate lid, connected through a flexible tube of $8 \mathrm{~mm}$ internal diameter to a funnel situated away from and above the level of the tank. Water containing food particles in the funnel was continually replenished, and a tap positioned immediately below the funnel regulated the rate at which the food was added to the tank. Food was added 
in 1 of 2 manners; either as a 'pulse' at a constant rate for a 10 to $15 \mathrm{~min}$ period once or twice during an experiment, or 'continuously' at a constant rate for a 1 to $3 \mathrm{~h}$ period during the experiment. Different methods of food addition were employed in order to provide a range of food concentrations within the experimental tank, resulting in the fish displaying each feeding mode over a wide range of swimming speeds.

From 3 to 5 subsamples were taken from the food vessel before addition of the food to the experimental tank. These replicates were preserved in $5 \%$ buffered formalin and later examined microscopically to identify, count and measure the food particles. Fifty individual food particles from each experiment were measured (maximum dimension) to determine average particle size. After enumeration, and in order to calculate experimental ration ( $\%$ wet fish body weight), the samples were individually concentrated onto preweighed Whatman GF/F $25 \mathrm{~mm}$ filter papers using a vacuum filter and their wet weights determined on a Sartorius micro-balance.
In experiments where the $R Q$ was determined, three $125 \mathrm{ml}$ water sampies were taken through one of the sealable ports for carbon dioxide analysis. Samples were collected at the same time as dissolved oxygen measurements were taken. Total carbon dioxide was determined using the methods described in Culberson (1981) and Jagner (1981): $\mathrm{pH}$ was determined on the NBS (National Bureau of Standards) scale and total alkalinity was measured using a Gran titration procedure. All calculations were also referenced to the NBS scale (P. Monteiro, Sea Fisheries Research Institute, pers comm.). The $R Q$ was calculated using the formula (Kutty 1968):

$$
R Q=\frac{\text { volume of } \mathrm{CO}_{2} \text { produced }}{\text { volume of } \mathrm{O}_{2} \text { consumed }}
$$

Respiration rates and mean swimming speed during non-feeding were plotted against temperature, and regressions were fitted to the data. Respiration rates were also plotted against mean swimming speed for each of the 3 activity states (non-feeding, filter-feeding
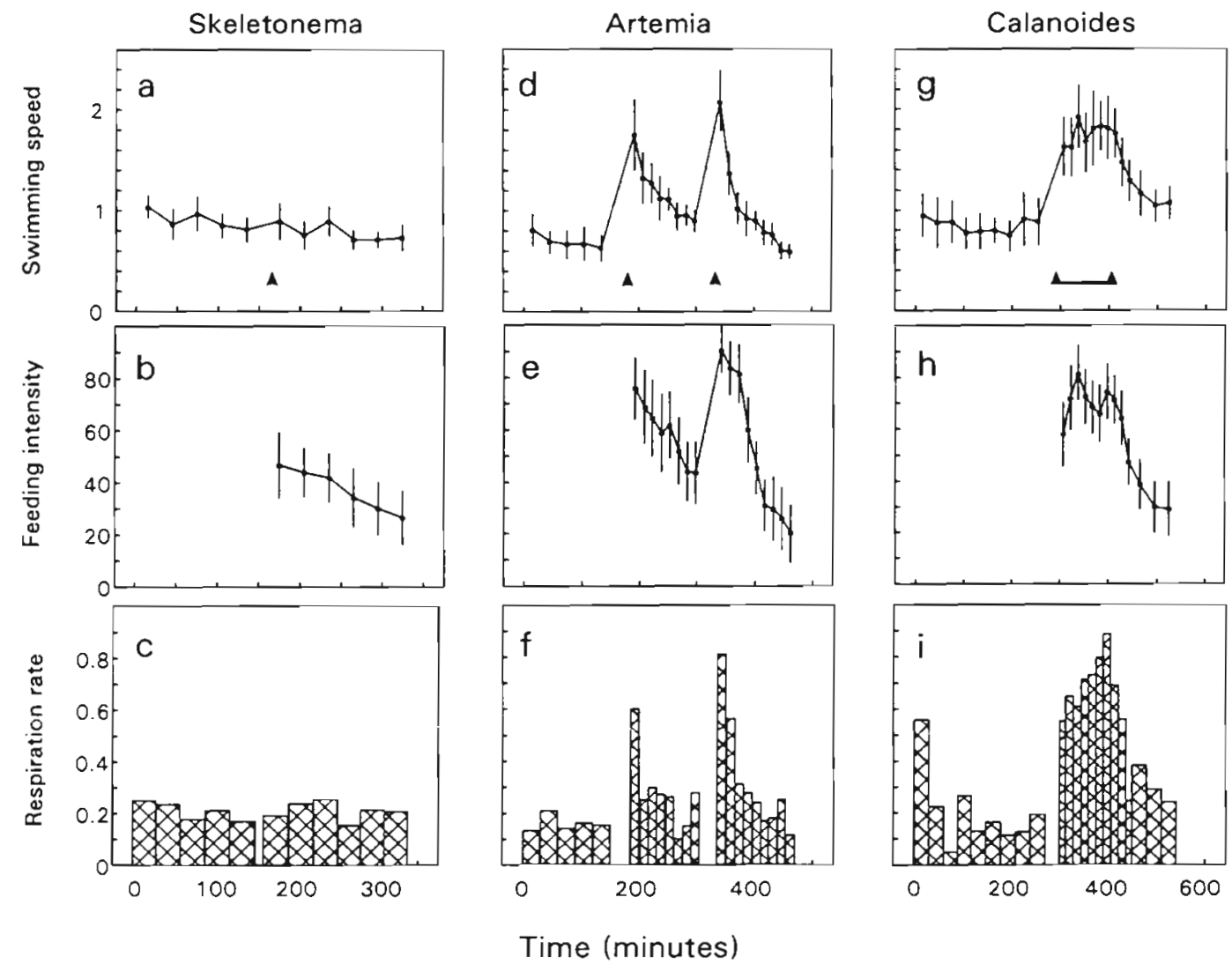

Fig. 1. Sardinops sagax. Swimming speed $\left(B L s^{-1}\right)$, feeding intensity (\% of school feeding) and respiration rate (mg $\mathrm{O}_{2} \mathrm{~g}^{-1}$ wet wt $h^{-1}$ ) of pilchard engaged in various activities: (a to c) filter-feeding on Skeletonema costatum and Nitzschia spp. (14 $\left.\pm 21 \mu \mathrm{m}\right)_{i}(\mathrm{~d}$ to f) filter-feeding on Artemia franciscana nauplii $(571 \pm 124 \mu \mathrm{m})_{i}(\mathrm{~g}$ to i) particulate-feeding on Calanoides carinatus (2411 \pm $134 \mathrm{~mm}$ ). Means \pm SD for swimming speed and feeding intensity are shown. Each graph shows the initial non-feeding response, followed by the feeding response. Time of food addition is indicated by single arrows (pulsed food addition) or arrows joined by a thick line (continuous food addition) on the swimming speed graphs 
and particulate-feeding), and regression equations were fitted to the data. In order to examine the effects on metabolism of feeding behaviour, as distinct from swimming speed, respiration rates were also plotted against mean feeding intensity. The slopes of the fitted regressions were taken as indicators of the energetic cost of a particular mode, and significant $(\mathrm{p}<0.05)$ differences in the slopes were tested for using a modified Student's $t$-test (Zar 1984).

\section{RESULTS}

Control experiments showed no significant ( $p>0.05$ ) change in dissolved oxygen concentration with time. In all other experiments, non-feeding activity was characterised by unchanging swimming speeds and low respiration rates (Fig. 1). When offered phytoplankton, pilchard showed no significant $(p>0.05)$ change in
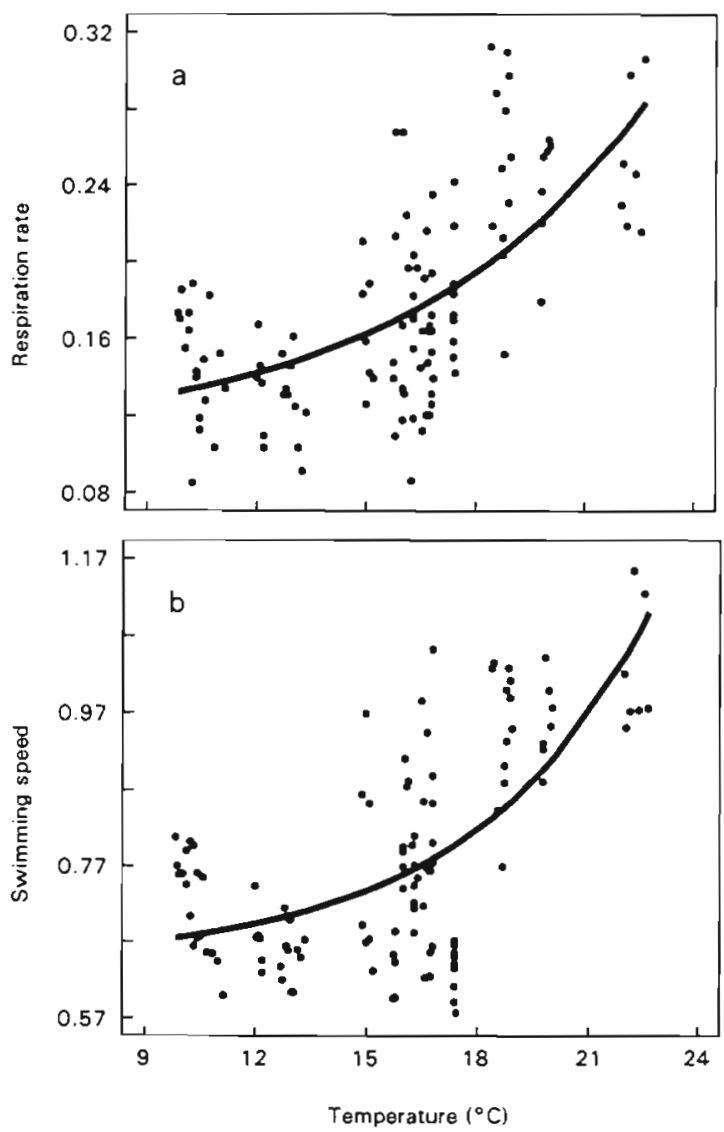

Fig. 2. Sardinops sagax. (a) Respiration rate $\left(\mathrm{mg} \mathrm{O}_{2} \mathrm{~g}^{-1}\right.$ wet wt $\left.\mathrm{h}^{-1}\right)$ and (b) swimming speed $\left(\mathrm{BL} \mathrm{s}^{-1}\right)$ as a function of temperature for non-feeding pilchard. Equations and statistical parameters for the fitted curves are: (a) $y=0.1058+0.0061 \mathrm{e}^{01492 x}$ $\mathrm{r}^{2}=0.43, \mathrm{n}=117, F=766.4, \mathrm{p}<0.001 ;$ (b) $y=0.6425+$ $0.0043 \mathrm{e}^{0.2057 x}, \mathrm{r}^{2}=0.45, \mathrm{n}=117, F=2219.7, \mathrm{p}<0.001$ swimming speed (Fig. 1a). Feeding intensity was initially moderate, with half of the school engaged in filter-feeding, and declined slowly as the fish removed the small food particles (Fig. 1b). Respiration rates when filter-feeding on phytoplankton were not significantly $(p<0.05)$ different to those determined during the preceding non-feeding period (Fig, 1C). The addition of zooplankton resulted in markedly increased swimming speeds, high feeding intensities, and an associated increase in respiration rate during both filterfeeding and particulate-feeding. Swimming speed declined rapidly as food concentrations declined in the pulsed-food experiment (Fig. 1d), but remained elevated during the continuous-food experiment (Fig. 1g). Feeding intensity mirrored swimming speed for both pulsed-food and continuous-food experiments, declining rapidly in the former (Fig. 1e) as the fish removed food particles through filter-feeding, and remaining elevated in the latter as the fish particulate-fed (Fig. 1h). Respiration rates increased by up to 6 -fold during periods of fast swimming speeds and high feeding intensities (Fig. 1f), with the highest rates being associated with particulate-feeding (Fig. 1i). Once food concentrations in the tank had been reduced by the fish, swimming speeds, feeding intensities and respiration rates declined gradually to pre-feeding levels.

The effect of temperature on respiration rate and swimming speed during non-feeding activity is shown in Fig. 2. Both respiration rate and mean swimming speed increased exponentially with temperature. A non-linear regression equation of the form

$$
y=a+b e^{c x}
$$

provided the best fit in both cases. Statistical parameters for the respiration rate/temperature and swimming speed/temperature regression equations are given in Fig. 2.

$Q_{10}$ values for pilchard were calculated from the data by applying the following formula:

$$
Q_{10}=\left(R_{2} / R_{1}\right)^{10 /\left(T_{2}-T_{1}\right)}
$$

where $R_{i}$ is the oxygen consumption rate at temperature $T_{i}$ (Schmidt-Nielsen 1982). Oxygen consumption rates were derived from the predictive exponential equation (Fig. 2a) at temperatures of $10,12,14,16,18$, 20 and $22^{\circ} \mathrm{C}$, and the $Q_{10}$ values for each temperature interval are given in Table 2. $Q_{10}$ values increased with increasing temperature over the temperature range observed, from 1.41 over $10-12^{\circ} \mathrm{C}$ to 2.33 over $20-22^{\circ} \mathrm{C}$, and had a mean $( \pm \mathrm{SD})$ value of $1.82 \pm 0.35$.

$R Q S$ were measured when the fish were displaying both non-feeding and particulate-feeding activity, and results from the $4 R Q$ experiments are presented in Table 3 . There was no significant $(t$-test; $t=-0.387$, $p=0.72$ ) difference between the average values 
Table 2. Sardinops sagax. Predicted oxygen consumption rates and $Q_{10}$ values for pilchard exhibiting non-feeding behaviour at various temperatures

\begin{tabular}{|lccc|}
\hline $\begin{array}{l}\text { Temperature } \\
\left({ }^{\circ} \mathrm{C}\right)\end{array}$ & $\begin{array}{c}\text { Respiration rate } \\
\left(\mathrm{mg} \mathrm{O}_{2} \mathrm{~g}^{-1}\right. \\
\left.\text { wet } \mathrm{wt} \mathrm{h}^{-1}\right)\end{array}$ & $\begin{array}{c}\text { Temperature } \\
\text { interval }\end{array}$ & $Q_{10}$ \\
\hline 10 & 0.133 & & \\
12 & 0.142 & $10-12$ & 1.41 \\
14 & 0.155 & $12-14$ & 1.53 \\
16 & 0.172 & $14-16$ & 1.69 \\
18 & 0.195 & $16-18$ & 1.87 \\
20 & 0.226 & $18-20$ & 2.09 \\
22 & 0.267 & $20-22$ & 2.33 \\
Mean $Q_{10}$ & & & $1.82 \pm 0.35$ \\
\hline
\end{tabular}

derived from non-feeding and particulate-feeding activity, and the mean $R Q$ for the combined data was $0.955 \pm 0.099$

The relationships between respiration rate and swimming speed for each of non-feeding, filter-feeding and particulate-feeding activity states are shown in Fig. 3. Non-feeding activity was characterized by slow swimming speeds ranging from 0.6 to $1.2 \mathrm{BL} \mathrm{s}^{-1}$ (= 15.4 to $30.7 \mathrm{~cm} \mathrm{~s}^{-1}$ ) and respiration rates of 0.08 to $0.32 \mathrm{mg}$ $\mathrm{O}_{2} \mathrm{~g}^{-1}$ wet wt $\mathrm{h}^{-1}$ (Fig. 3a). The plot of swimming speed coefficient of variation (SSCV) versus swimming speed indicates that non-feeding is a highly variable activity, with SSCVs ranging from 8 to $40 \%$ of the means (Fig. 3b). The average non-feeding (routine) respiration rate was $0.178 \pm 0.055 \mathrm{mg} \mathrm{O}_{2} \mathrm{~g}^{-1}$ wet wt $\mathrm{h}^{-1}$ at a mean swimming speed of $0.78 \pm 0.14 \mathrm{BL} \mathrm{s}^{-1}(=20.0 \pm$ $3.6 \mathrm{~cm} \mathrm{~s}^{-1}$ ).

Swimming speed during filter-feeding ranged from 0.6 to $2.6 \mathrm{BL} \mathrm{s}^{-1}$ (= 15.4 to $66.6 \mathrm{~cm} \mathrm{~s}^{-1}$ ), with respiration rates increasing proportionately with swimming speed and ranging from 0.07 to $1.03 \mathrm{mg} \mathrm{O}_{2} \mathrm{~g}^{-1}$ wet wt $\mathrm{h}^{-1}$ (Fig. 3c). The plot of SSCV versus swimming speed (SSCV ranging from 9 to $33 \%$ ) for filter-feeding shows slightly less variability than that for non-feeding activity, suggesting that filter-feeding may be a more consistent activity state (Fig. 3d). Particulatefeeding fish exhibited swimming speeds of 1.0 to $2.0 \mathrm{BL} \mathrm{s}^{-1}$ (= 25.6 to $51.2 \mathrm{~cm} \mathrm{~s}^{-1}$ ), and respiration rate was again proportional to swimming speed (Fig. 3e), ranging from 0.20 to $0.90 \mathrm{mg} \mathrm{O}_{2} \mathrm{~g}^{-1}$ wet wt $\mathrm{h}^{-1}$. The
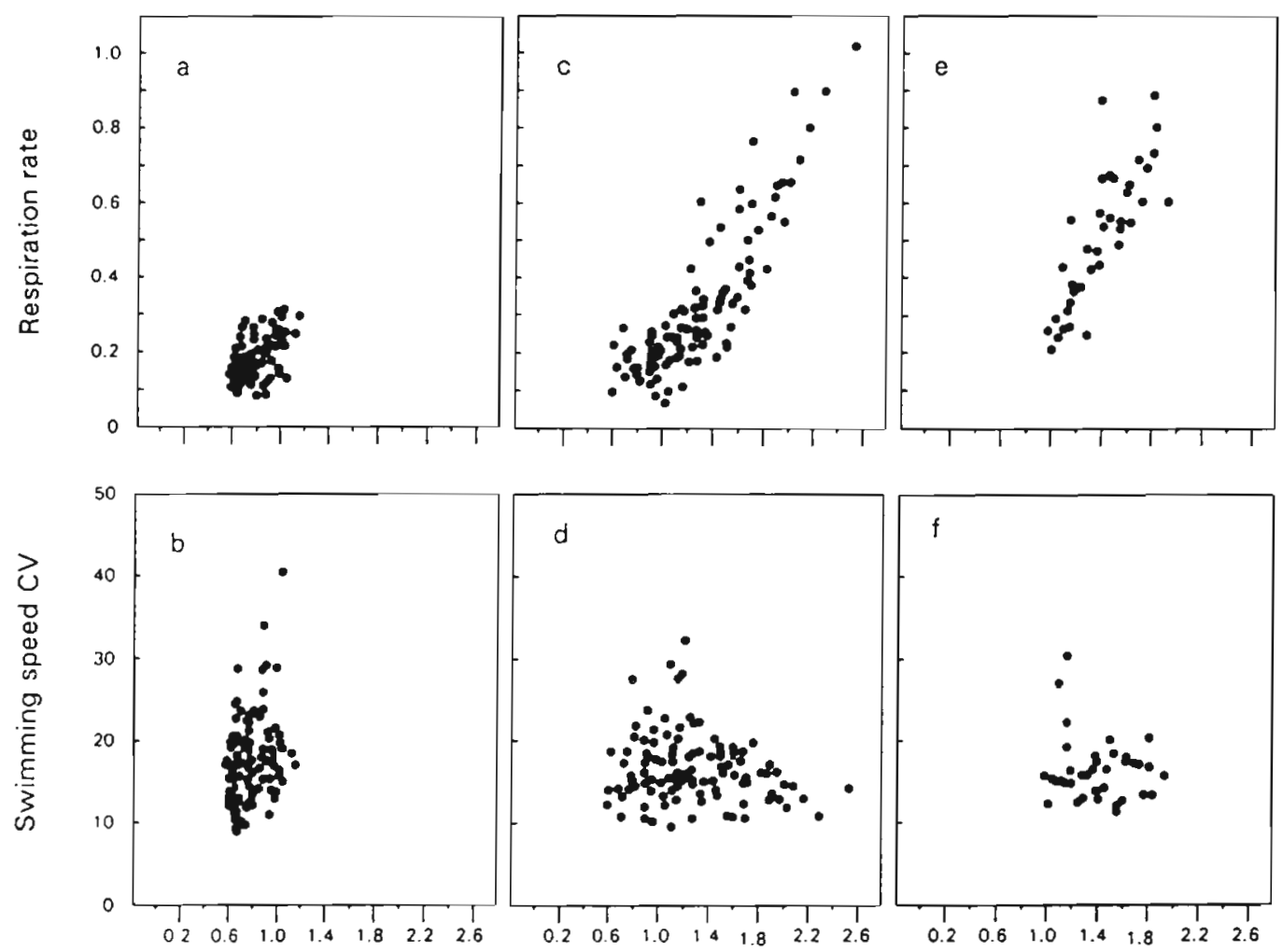

Swimming speed $\left(B L s^{-1}\right)$

Fig. 3. Sardinops sagax. Relationship between respiration rate ( $\mathrm{mg} \mathrm{O}_{2} \mathrm{~g}^{-1}$ wet $\mathrm{wt}^{\mathrm{h}^{-1}}$ ), coefficient of variation (CV) of swimming speed $(\%)$ and swimming speed $\left(B L s^{-1}\right)$ for pilchard engaged in $(a, b)$ non-feeding, $(c, d)$ filter-feeding and (e, f) particulatefeeding 
Table 3. Sardinops sagax. Oxygen consumption, carbon dioxide production, and calculated $R Q$ s for pilchard during various activity states

\begin{tabular}{|lccc|}
\hline Expt & $\begin{array}{c}\mathrm{O}_{2} \text { consumption } \\
\left(\mathrm{mg} \mathrm{g}^{-1} \text { wet } \mathrm{wt} \mathrm{h}^{-1}\right)\end{array}$ & $\begin{array}{c}\mathrm{CO}_{2} \text { production } \\
\left(\mathrm{mg} \mathrm{g}^{-1} \text { wet wt h }\right.\end{array}$ & $R Q$ \\
\hline 8: non-feeding & 0.165 & 0.168 & 1.018 \\
8: particulate-feeding & 0.354 & 0.386 & 1.090 \\
9: non-feeding & 0.255 & 0.267 & 1.047 \\
9: particulate-feeding & 0.485 & 0.430 & 0.887 \\
10: non-feeding & 0.248 & 0.217 & 0.875 \\
10: particulate-feeding & 0.540 & 0.507 & 0.939 \\
12: non-feeding & 0.179 & 0.148 & 0.827 \\
Mean $R Q$ & & & $0.955 \pm 0.099$ \\
\hline
\end{tabular}

0.085; $D_{\text {part }}=0.137, D_{005,39}=0.140$ ). Hence regressing untransformed respiration rate against swimming speed was justified in this instance.

The slope of a regression was taken as indicative of the relative energetic cost of that particular feeding mode (James \& Probyn 1989). All 3 slopes were significantly $(p<0.05)$ different from each other, with nonfeeding showing the lowest slope value, filter-feeding an intermediate value and the highest slope value being that derived for particulate-

plot of SSCV versus swimming speed (SSCV ranging from 12 to $31 \%$ ) for particulate-feeding also shows less variability than that for nonfeeding activity (Fig. 3f).

Linear regressions were found to provide the best fit to the respiration rate/swimming speed data for all 3 activity states, and predictive plots are presented in Fig. 4. The equation and statistical parameters for each regression are given in Table 4 . The linear relationships between respiration rate and swimming speed for all 3 activity states derived in this study are inconsistent with other studies, which reported a log-linear relationship between these variables (Brett 1964, 1965, Brett \& Sutherland 1965 . Muir \& Niimi 1972, Beamish 1981, 1990, Durbin et al. 1981, James \& Probyn 1989). Log transformations, such as the ones employed by those authors, are used to correct for heteroscedasticity, to transform multiplicative effects into additive ones, or to normalize data (Zar 1984). To test for homoscedasticity, respiration rate residuals from the regressions for each activity state of pilchard derived in this study were plotted as a function of their corresponding swimming speeds (Fig. 4b-d) and their homoscedasticity assessed by inspection. Additionally, the residuals were examined for normality of distribution using the Kolmogorov-Smirnov test (Zar 1984). No heteroscedastic trends were seen in any of the 3 cases, and residual distribution was normal at the $\mathrm{p}<0.05$ level ${ }_{\left(D_{\text {non }}\right.}=0.057$, $D_{0.05,119}=0.081 ; D_{\text {filt. }}=0.052, D_{0.05,111}=$
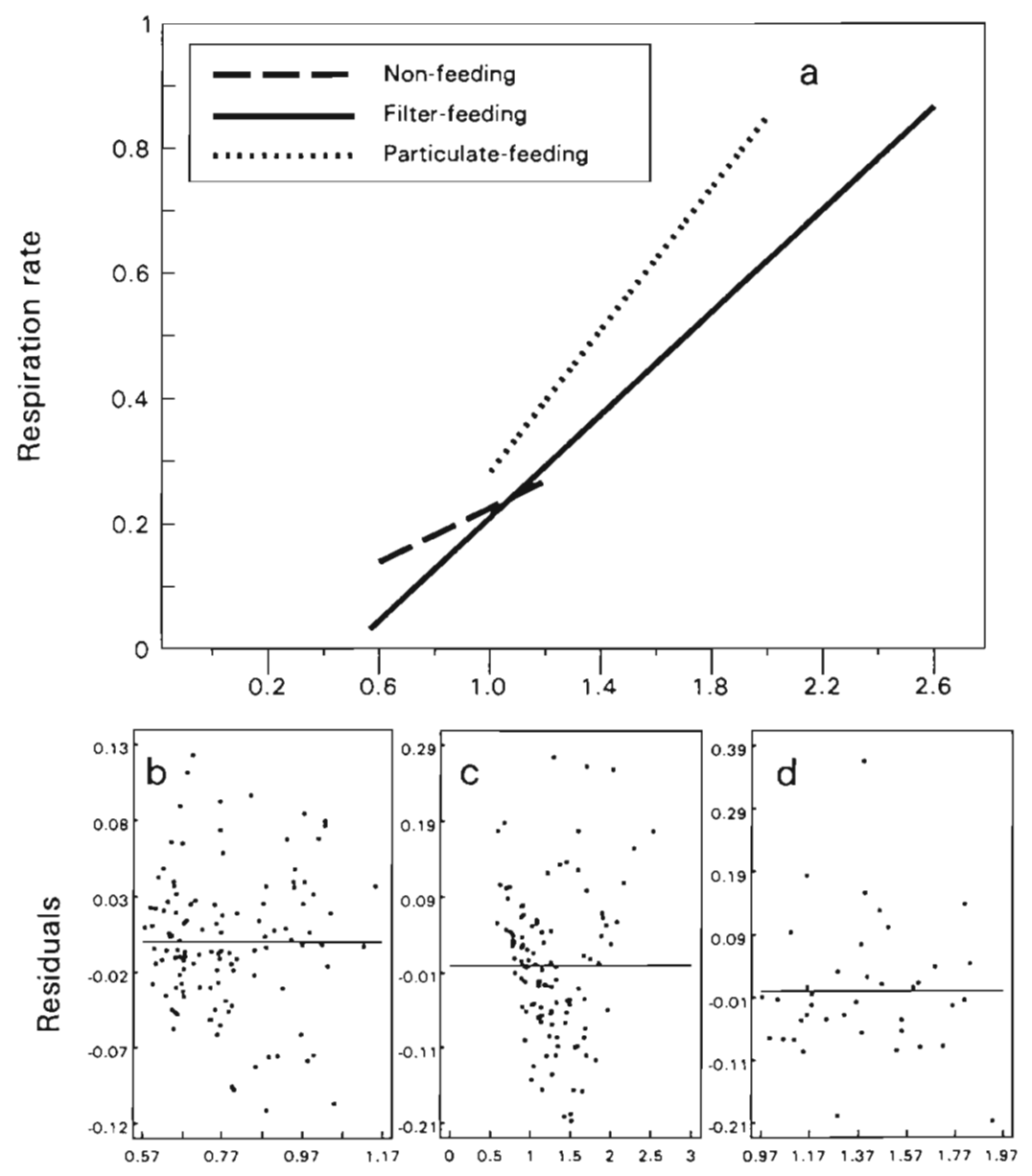

Swimming speed (BL $\mathrm{s}^{-1}$ )

Fig. 4. Sardinops sagax. (a) Derived linear regressions of respiration rate (mg $\mathrm{O}_{2}$ $\mathrm{g}^{-1}$ wet $\mathrm{wt} \mathrm{h}^{-1}$ ) as a function of swimming speed $\left(\mathrm{BL} \mathrm{s}^{-1}\right)$ for pilchard engaged in various activities. Parameters for the regression equations are given in Table 4. (b to d) Respiration rate residuals plotted against their corresponding swimming speeds for (b) non-feeding, (c) filter-feeding and (d) particulate-feeding activity states 
Table 4. Sardinops sagax. Statistical parameters for the predictive equations of respiration rate as a function of swimming speed for pilchard engaged in non-, filter-and particulate-feeding. The equations are of the form $y=m x+c$, where $y$ is respiration rate $\left(\mathrm{mg} \mathrm{O}_{2} \mathrm{~g}^{-1}\right.$ wet $\left.w \mathrm{~h} \mathrm{~h}^{-1}\right), x$ is swimming speed $\left(\mathrm{BL} \mathrm{s} \mathrm{s}^{-1}\right), m$ is the slope and $c$ is the intercept. SE values for the slope and intercept are given, as are the regression $F$-ratio and significance of the derived regressions. All slopes are significantly $(\mathrm{p}<0.05)$ different to each other

\begin{tabular}{|lccc|}
\hline Parameter & Non-feeding & Filter-feeding & Particulate-feeding \\
\hline $\mathrm{n}$ & 119 & 111 & 39 \\
Slope & $0.2219 \pm 0.0304$ & $0.4131 \pm 0.0234$ & $0.5711 \pm 0.0660$ \\
Intercept & $0.0047 \pm 0.0241$ & $-0.2035 \pm 0.0312$ & $-0.2891 \pm 0.0935$ \\
$\mathrm{r}^{2}$ & 0.31 & 0.74 & 0.67 \\
F-ratio & 53.3 & 312.8 & 75.0 \\
$\mathrm{p}$ & $<0.001$ & $<0.001$ & $<0.001$ \\
\hline
\end{tabular}

activity state for Sardinops sagax and that feeding of either mode is energetically more expensive than non-feeding. Standard (basal) metabolic rate was estimated by extrapolation of the relationship between non-feeding swimming speed and respiration rate to $0 \mathrm{BL} \mathrm{s}^{-1}$, which yielded a standard metabolic rate of $0.009 \pm 0.024 \mathrm{mg} \mathrm{O}_{2} \mathrm{~g}^{-1}$ wet wt $\mathrm{h}^{-1}$.

The relationships between respiration rate and feeding intensity for both filter-feeding and particulatefeeding are shown in Fig. 5. During filter-feeding, high respiration rates tended to be associated with high feeding intensities (Fig. 5a), although there was con- siderable scatter between these variables. The plot of feeding intensity coefficient of variation (FICV) versus feeding intensity for filter-feeding showed a very marked decline in CVs at higher feeding intensities (Fig. 5b), indicating that the school behaved uniformly at high filter-feeding intensities. High respiration rates were also associated with high feeding intensities for pilchard engaged in particulate-feeding (Fig. 5c), and there was less scatter between these variables for particulate-feeding than for filterfeeding. The plot of FICV versus feeding intensity for particulate-feeding showed an exponential decline in $\mathrm{CV}$ with feeding intensities (Fig. 5d).

Significant regressions were derived for the respiration rate/feeding intensity relationships for both feeding modes, with an exponential equation best describing the relationship in each case. The predictive curves are presented in Fig. 6, and the equation and statistical parameters for each regression are given in Table 5. The variance in respiration rate explained by feeding intensity for filter-feeding was much less than that explained by swimming speed $(24$ and $74 \%$ respectively), but similar for particulate-feeding $(64$ and $67 \%$
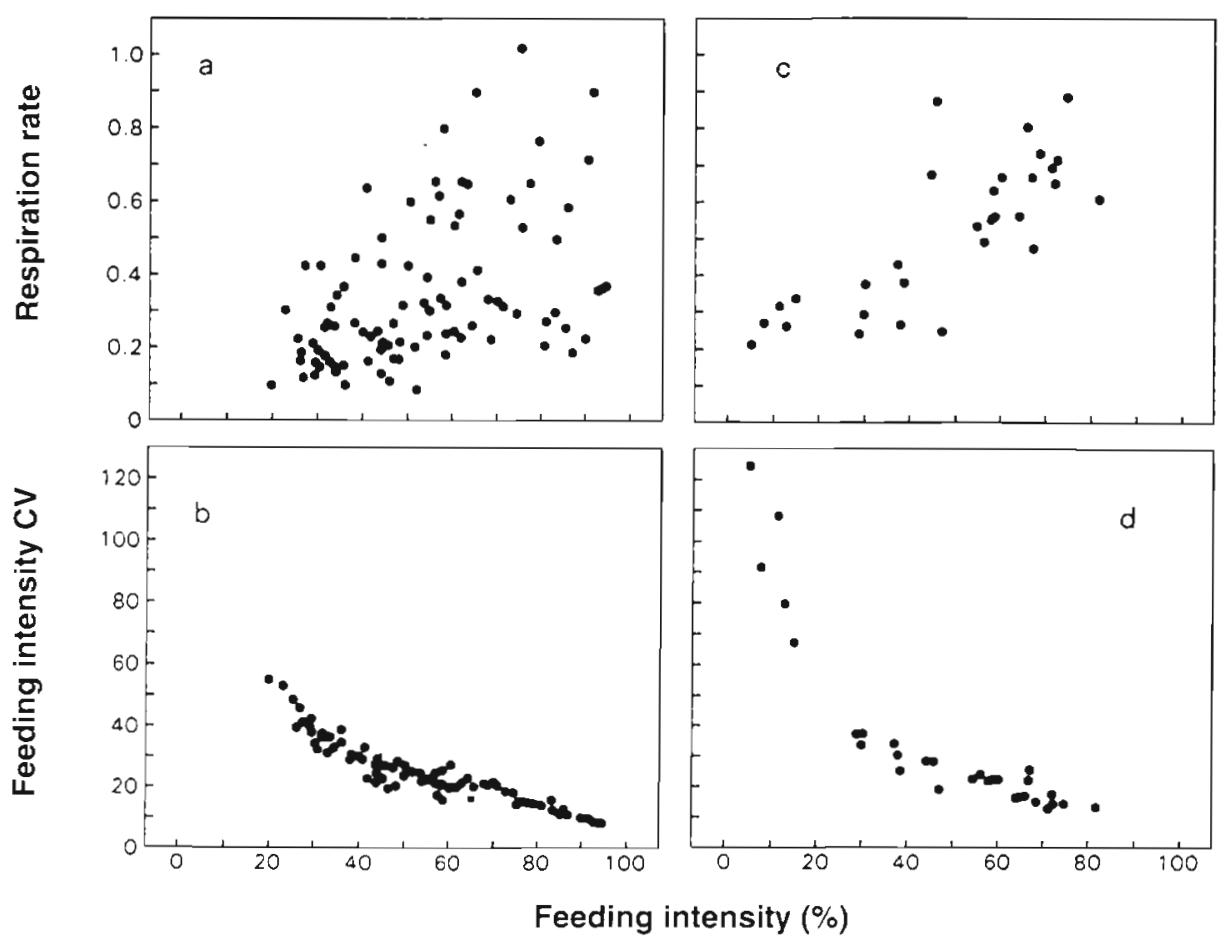

Fig. 5. Sardinops sagax. Relationship between respiration rate ( $\mathrm{mg} \mathrm{O} \mathrm{O}_{2} \mathrm{~g}^{-1}$ wet $\mathrm{wt} \mathrm{h}^{\mathrm{h}}$ ), coefficient of variation (CV) of feeding intensity $(\%)$ and feeding intensity $(\%)$ for pilchard engaged in $(a, b)$ filter-feeding and $(c, d)$ particulate-feeding 


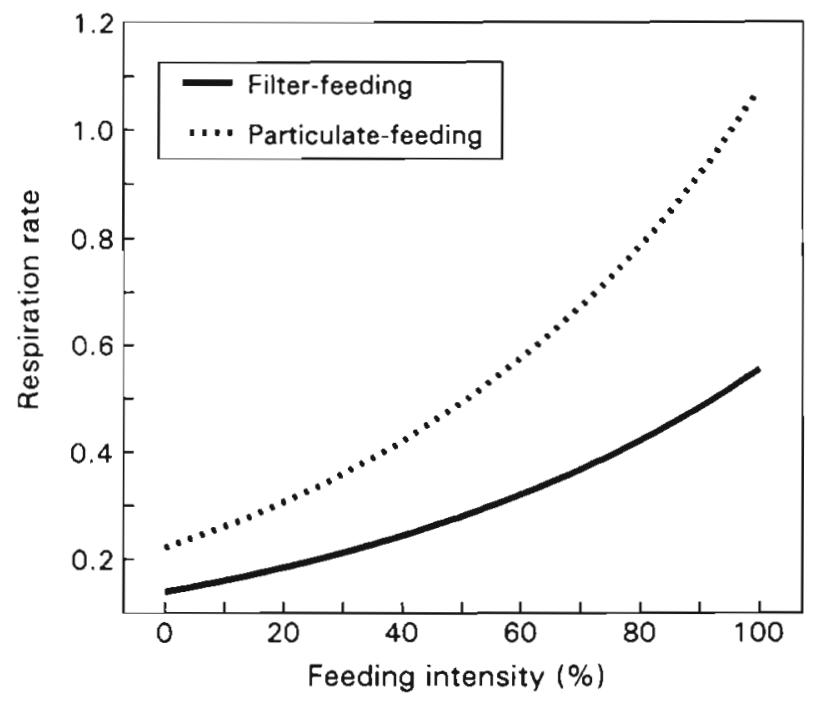

Fig. 6. Sardinops sagax. Derived regressions of respiration rate ( $\mathrm{mg} \mathrm{O}_{2} \mathrm{~g}^{-1}$ wet $\mathrm{wt}^{-1}$ ) as a function of feeding intensity $(\%)$ for pilchard engaged in filter-feeding and particulatefeeding. Parameters for the regression equations are given in Table 5

respectively). This suggests that swimming speed is the prime determinant of respiration rate when filterfeeding, but that feeding intensity (i.e. feeding behaviour) assumes equal importance as a determinant of respiration rate when the fish are engaged in particulate-feeding.

Feeding intensity was significantly correlated with swimming speed during both filter-feeding and particulate-feeding, with high feeding intensities associated with elevated swimming speeds (Fig. 7). These high correlations prevented the use of these 2 variables in deriving multiple regressions of respiration rate for both feeding modes. This is due to the fact that inter-

Table 5. Sardinops sagax. Statistical parameters for the predictive equations of respiration rate as a function of feeding intensity for pilchard engaged in filter-and particulatefeeding. The equations are of the form $y=e^{c+m x}$, where $y$ is respiration rate $\left(\mathrm{mg} \mathrm{O}_{2} \mathrm{~g}^{-1}\right.$ wet $\left.w \mathrm{~h} \mathrm{~h}^{-1}\right), \mathrm{x}$ is feeding intensity $(\%), m$ is the slope and $c$ is the intercept. SE values for the slope and intercept are given, as are the regression F-ratio and significance of the derived regressions

\begin{tabular}{|lcc|}
\hline Parameter & Filter-feeding & Particulate-feeding \\
\hline $\mathrm{n}$ & 98 & 39 \\
Slope & $0.0137 \pm 0.0025$ & $0.0158 \pm 0.0019$ \\
Intercept & $-1.9639 \pm 0.1411$ & $-1.4973 \pm 0.0990$ \\
$\mathrm{r}^{2}$ & 0.24 & 0.64 \\
F-ratio & 30.2 & 66.9 \\
$\mathrm{p}$ & $<0.001$ & $<0.001$ \\
\hline
\end{tabular}

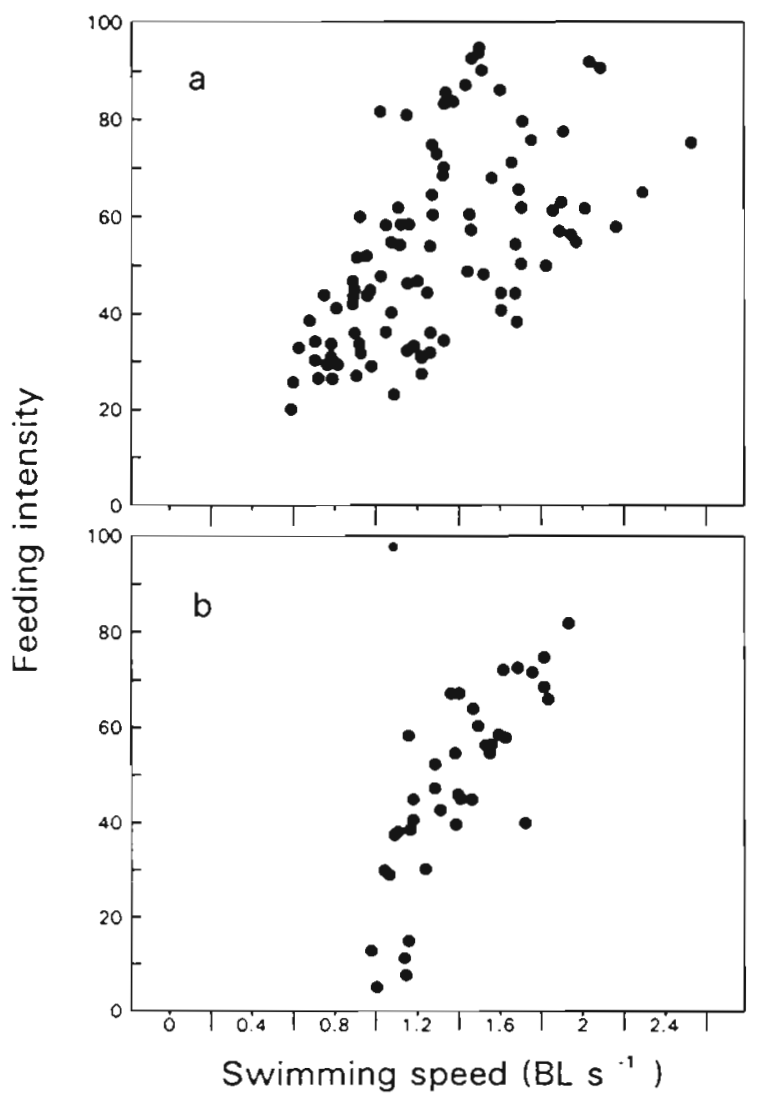

Fig. 7. Sardinops sagax. Relationship between feeding intensity $(\%)$ and swimming speed $\left(\mathrm{BL} \mathrm{s}^{-1}\right)$ for pilchard engaged in (a) filter-feeding and (b) particulate-feeding

correlation among independent variables generates spurious conclusions in multiple regressions (Zar 1984).

\section{DISCUSSION}

This study has described the relationship between non-feeding (routine) respiration rate and temperature, derived mean values for $Q_{10}$ and $R Q$, and elucidated the effects of swimming speed and feeding behaviour on the metabolism of adult pilchard Sardinops sagax.

The effect of temperature on the active metabolism of fish has been reviewed by Fry (1971), but there appears to be no single pattern to describe the relationship for all species (Beamish 1990). For Sardinops sagax, elevated temperatures resulted in increased respiration and swimming speed, with both variables increasing at an increasing rate with temperature. The $Q_{10}$ for $S$. sagax calculated here $\left(1.82\right.$ over 10 to $22^{\circ} \mathrm{C}$ ) is both lower than that determined for the same species elsewhere in its range, and lower than that found for other clupeoids. Villacencio et al. (1981, in Blaxter \& 
Hunter 1982) calculated a $Q_{10}$ of 3.2 for juvenile $(8.5 \mathrm{~cm}) \mathrm{S}$. sagax between 15 and $20^{\circ} \mathrm{C}$, whereas Villacencio (1981, in Blaxter \& Hunter 1982) reported a $Q_{10}$ of 2.6 for adult $(12 \mathrm{~cm})$ anchovetta Engraulis ringens between 15 and $20^{\circ} \mathrm{C}$. Using the data in Hettler's (1976) Table I enables a $Q_{10}$ of 2.1 to be calculated for young (74 to $81 \mathrm{~g}$ ) Atlantic menhaden Brevoortia tyrannus between 10 and $25^{\circ} \mathrm{C}$. Talbot \& Baird (1985) reported a $Q_{10}$ of 2.3 for estuarine round herring Gilchristella aestuarius between 15 and $25^{\circ} \mathrm{C}$. The low $Q_{10}$ value determined for $S$. sagax in this study may be indicative of a high degree of eurythermy. This suggestion appears credible, since pilchard are common members of the pelagic fish component in several eastern boundary current systems such as the Benguela, California and Humboldt Current Systems (Crawford 1987). These systems are characterised by equatorward surface flow and coastal upwelling, resulting in high sea surface temperature variability (Parrish et al. 1983).

$R Q$ indicates the type of physiological fuel involved in metabolism and, in fish, typically ranges from 0.7 for the catabolism of fats, through 0.9 for protein, to 1.0 for carbohydrates (Brett \& Groves 1979). The mean $R Q$ value of 0.96 for pilchard suggests that metabolism is based on the breakdown of both protein and carbohydrates, although in general fish utilize dietary carbohydrates poorly (Brett \& Groves 1979). This contrasts with the suggestion of Lasker (1970), who stated that Pacific sardine Sardinops caerulea (= S. sagax; Parrish et al. 1989) metabolize fat as their major energy source.
Lasker (1970) however gave no information on how such a conclusion was derived. James \& Probyn (1989) showed Engraulis capensis to have an $R Q$ of $0.915 \pm$ 0.183 , and suggested that protein was the metabolic fuel for this species. Although there is no statistical difference between the mean $R Q$ values of these 2 clupeoids $(t=-0.616, \mathrm{p}=0.55)$, the higher value for pilchard suggests a greater carbohydrate utilization by this species. This lends support to the hypothesis (Davies 1957, van der Lingen 1994) that phytoplankton is a more important dietary component for pilchard than for anchovy, although both species consume phytoplankton (James 1988).

The standard respiration rate of pilchard estimated in this study, $0.009 \mathrm{mg} \mathrm{O}_{2} \mathrm{~g}^{-1}$ wet $\mathrm{wt} \mathrm{h}^{-1}$, is an order of magnitude lower than that calculated from 34 fish species $\left(0.089 \mathrm{mg} \mathrm{O}_{2} \mathrm{~g}^{-1}\right.$ wet $\left.\mathrm{wt} \mathrm{h}^{-1}\right)$ by Brett \& Groves (1979). However, estimates of standard metabolic rate for pelagic fish derived by extrapolation are of limited ecological value, since such fish are never inactive but shift through a series of activity states including feeding, spawning, and horizontal and vertical migration (James \& Probyn 1989). A more relevant standard metabolic rate value is $0.138 \mathrm{mg} \mathrm{O}_{2} \mathrm{~g}^{-1}$ wet $\mathrm{wt} \mathrm{h} \mathrm{h}^{-1}$; the predicted respiration rate at the lowest observed nonfeeding swimming speed.

The routine respiration rate determined in this study for adult Sardinops sagax lies within the range of routine rates estimated for other clupeoids (Table 6). The high value observed by Lasker (1970) was derived

Table 6. Routine (non-feeding) respiration rates $\left(\mathrm{mg} \mathrm{O}_{2} \mathrm{~g}^{-1}\right.$ wet $\left.\mathrm{wt} \mathrm{h}^{-1}\right)$, fish size, temperature $\left({ }^{\circ} \mathrm{C}\right)$ and $\mathrm{swimming}$ speed $\left(\mathrm{BL} \mathrm{s}^{-1}\right.$ ) of various clupeoids

\begin{tabular}{|c|c|c|c|c|c|}
\hline Species & $\begin{array}{l}\text { Routine } \\
\text { respiration rate }\end{array}$ & $\begin{array}{l}\text { Fish size (length } \\
\text { or wet weight) }\end{array}$ & Temperature & Swimming speed & Source \\
\hline \multirow[t]{3}{*}{ Sardinops sagax } & $0.178 \pm 0.055$ & $25.6 \mathrm{~cm} \mathrm{TL} / 146 \mathrm{~g}$ & $9.7-22.7$ & $0.78 \pm 0.14$ & This study \\
\hline & $0.32^{\mathrm{a}}$ & $12-25 \mathrm{~cm} \mathrm{SL}$ & $16.5-22$ & 0.42 & Lasker $(1970)$ \\
\hline & 0.053 & 'Juvenile' & & & $\begin{array}{l}\text { Villavincencio et al. (1981, in } \\
\text { James \& Probyn 1989) }\end{array}$ \\
\hline \multirow[t]{2}{*}{ Clupea harengus } & $0.20-0.25$ & & & & $\begin{array}{l}\text { Aneer }(1979, \text { in James \& } \\
\text { Probyn 1989) }\end{array}$ \\
\hline & $0.093 \pm 0.005$ & $28.2 \mathrm{~cm} \mathrm{TL}$ & 9.3 & 0.3 & Johnstone et al. (1993) \\
\hline C. harengus membras & 0.2 & $12-27 \mathrm{~cm} \mathrm{~L}$ & $10-11$ & 'Normal' & $\begin{array}{l}\text { Chekunova (1979, in } \\
\text { Johnstone et al. 1993) }\end{array}$ \\
\hline \multirow[t]{2}{*}{ Brevoortia tyrannus } & $0.263-0.314$ & $23.3 \mathrm{~g}$ & $23-24$ & & Hettler (1976) \\
\hline & $0.100 \pm 0.009$ & $25.8 \mathrm{~cm} \mathrm{FL} / 302 \mathrm{~g}$ & $20 \pm 1$ & $0.47 \pm 0.06$ & Durbin et al. (1981) \\
\hline Engraulis ringens & 0.084 & & & & $\begin{array}{l}\text { Villavincencio (1981, un } \\
\text { James \& Probyn 1989) }\end{array}$ \\
\hline E. capensis & $0.111 \pm 0.033$ & $9.32 \mathrm{~cm} \mathrm{~L}$ & $16.2 \pm 0.4$ & $1.73 \pm 0.29$ & James \& Probyn (1989) \\
\hline
\end{tabular}


from experiments performed upon single sardines in a small ( 7.81 ) respiration chamber and is likely to be the result of laboratory artefact such as stress, attributable to confinement and isolation from the shoal (Blaxter \& Hunter 1982). The low value recorded by Villavincencio (1981, in James \& Probyn 1989) for this species is surprising, since this value is for 'juvenile' fish and respiration rates usually decrease with increasing size both within and among species (Brett \& Groves 1979). Clupeoids show large metabolic ranges compared to less active species (Durbin et al. 1981), with the ratio of active to routine respiration rate attaining a level as high as 10.7 for Engraulis capensis (James \& Probyn 1989, their Table V). Whereas the maximum active respiration rate for pilchard was 5.8 times greater than the average routine rate, the true active (sensu Brett 1965) respiration rate remains unknown, since the experiments reported here measured respiration rates during voluntary swimming only.

The slopes of the predicted respiration rate/swimming speed relationships derived in this study demonstrate that at any given swimming speed, filter-feeding by adult Sardinops sagax is energetically cheaper than particulate-feeding. This result would tend to support the hypothesis that filter-feeding is the principal food acquisition mode of pilchard (Davies 1957, King \& Macleod 1976, van der Lingen 1994). However, the feeding mode that realises the greatest return, in terms of energy expenditure versus energy gain, is dependent upon the size and concentration of food particles present. Pilchard have been shown to exclusively filter-feed on particles less than $1230 \mu \mathrm{m}$ total length, and to filter-feed or particulate-feed on particles greater than this size, depending upon concentration (van der Lingen 1994).

The results presented here differ from those determined for Engraulis capensis, a species which is also capable of both filter-feeding and particulate-feeding (James \& Findlay 1989). Filter-feeding by anchovy was shown to be energetically more expensive than particulate-feeding, leading James \& Probyn (1989) to hypothesise that the change in body shape and increased resultant drag associated with flared operculae during filter-feeding was responsible for increased metabolic costs. Following James \& Probyn's (1989) line of reasoning, it would intuitively be expected that this would also apply to pilchard, since the act of filtering also results in marked changes in body shape.

However, viscous force, which is proportional to fish surface area (Webb 1975) and results in drag, is only one of the forces acting upon a body submerged in a fluid. Gravitational and inertial (proportional to fish mass) forces also act upon moving bodies, although gravitational forces are insignificant when the body is well submerged (Webb 1975). The relative importance of inertial and viscous forces is expressed in the dimensionless Reynolds number $\left(\mathrm{R}_{\mathrm{e}}\right)$, which is a function of organism size, velocity, fluid density and kinematic viscosity (Videler 1993). $R_{e}$ increases with increasing organism size, ranging from $<1$ for protozoa to $10^{8}$ for the blue whale Balaenoptera musculus (Webb 1975, Videler 1993). Hence viscous forces are dominant for small organisms whereas inertial forces are dominant for larger organisms.

The relative importance of viscous forces is therefore likely to be higher for anchovy, since anchovy are smaller than pilchard and, at any given swimming speed, anchovy will have a lower $\mathrm{R}_{e}$, although inertial forces will dominate for both species. Estimates of $R_{e}$ calculated using Eq. (12) of Webb (1975), range from $4.2 \times 10^{4}$ to $1.1 \times 10^{5}$ for pilchard, and $1.7 \times 10^{4}$ to $4.2 \times$ $10^{4}$ for anchovy, swimming from 20 to $50 \mathrm{~cm} \mathrm{~s}^{-1}$ at $15^{\circ} \mathrm{C}$. This difference between pilchard and anchovy may be the reason for the observed differences in feeding-mode metabolic costs. Thus, turning frequently to capture prey by particulate-feeding is relatively more expensive for the heavier pilchard, whereas the increased drag associated with filter-feeding is relatively more expensive for the smaller anchovy.

A comparison of the relative energetic costs of both feeding modes for these 2 species is given in Fig. 8a. Although the respiration rate of particulate-feeding anchovy was similar to that of pilchard for both feeding modes over the same swimming speed range, filterfeeding by anchovy was exceptionally expensive, particularly at speeds above $30 \mathrm{~cm} \mathrm{~s}^{-1}\left(=3.2 \mathrm{BL} \mathrm{s}^{-1}\right)$. Fig. $8 \mathrm{~b}$ depicts the predicted respiration rate as a function of swimming speed for pilchard, anchovy and the obligate filter-feeding menhaden Brevoortia tyrannus (Durbin \& Durbin 1975) engaged in filter-feeding only. Although the data set for menhaden is small, with swimming speeds ranging from 25 to $45 \mathrm{~cm} \mathrm{~s}^{-1}$ (= 1 to $\left.1.7 \mathrm{BL} \mathrm{s}^{-1}\right)$, the predicted respiration rate versus swimming speed equation derived by Durbin et al. (1981) does not appear to be significantly different from that derived for pilchard, although both are distinctly lower than that for anchovy. Menhaden and pilchard used to derive these equations were of a similar length ( $25.8 \mathrm{~cm}$ fork length, and $25.6 \mathrm{~cm}$ TL respectively) and were substantially larger than the anchovy $(9.3 \mathrm{~cm} \mathrm{TL})$. The similarity in absolute swimming speeds between these 3 species is surprising, given that larger fish have faster absolute swimming speeds than smaller fish (Videler 1993).

These observations suggest a general principle applicable to clupeoid fish capable of filter-feeding: that the energetic cost attributable to filtering decreases in relative importance with increasing fish size. This principle is supported by the data of Janssen (1976), who observed that whereas alewives Alosa pseudoharen- 


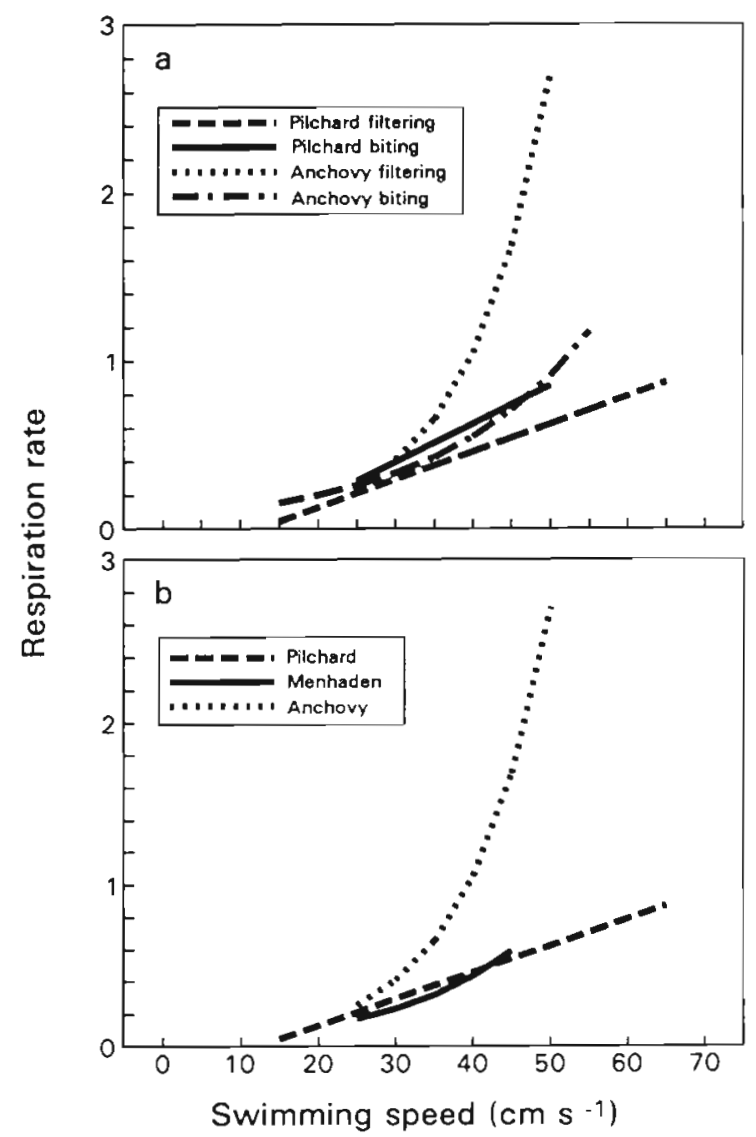

Fig. 8. Sardinops sagax, Engraulis capensis, Brevoortia tyrannis. Predicted respiration rates ( $\mathrm{mg} \mathrm{O}_{2} \mathrm{~g}^{-1}$ wet wt $\mathrm{h}^{-1}$ ) as a function of swimming speed $\left(\mathrm{cm} \mathrm{s}^{-1}\right)$ for (a) pilchard and anchovy engaged in both filter-feeding and particulate-feeding. and (b) pilchard, anchovy and menhaden engaged in filterfeeding only. Predictive equations are from James \& Probyn (1989) for anchovy (mean wet wt $7.1 \mathrm{~g}$, mean TL $9.3 \mathrm{~cm}$ ) and from Durbin et al. (1981) for menhaden (mean wet wt $302 \mathrm{~g}$. mean FL $25.8 \mathrm{~cm}$ )

gus are capable of both filter-feeding and particulatefeeding, different-sized individuals within the same school displayed different feeding behaviours when offered the same food. Large (17.8 to $18.0 \mathrm{~cm} \mathrm{TL}$ ) fish filter-fed exclusively upon Daphnia pulex whilst smaller ( 4.9 to $11.4 \mathrm{~cm} \mathrm{TL}$ ) fish were exclusively particulate-feeders Similarly, gizzard shad Dorosoma cepedianum displays a dietary switch at a size of $2.5 \mathrm{~cm}$ caudal length from exclusively zooplankton to one comprising phytoplankton, zooplankton, and detritus, implying a change in feeding mode from particulatefeeding to filter-feeding at this size (Drenner et al. 1982). Pilchard also display a dietary switch, the proportion by volume of zooplankton decreasing from $87.3 \%$ for fish $<10 \mathrm{~cm}$ SL to $22.9 \%$ for fish $>10 \mathrm{~cm} \mathrm{SL}$ (King \& Macleod 1976). Although the change in diet and feeding mode utilisation with increasing size for pilchard and gizzard shad is a function of morphological development, it is possible that hydrodynamic factors may also influence this switch.

That particulate-feeding is energetically more expensive than filter-feeding in Sardinops sagax may be due to the different swimming behaviour associated with each feeding mode. Particulate-feeding is a more complex activity than filtering, since it involves frequent changes in direction and abrupt accelerations and decelerations as the fish align themselves towards specific food particles (van der Lingen 1994). In contrast, filter-feeding involves a 'constant-motion' behaviour pattern, with the fish maintaining a more consistent swimming speed and displaying low amplitude changes in direction (van der Lingen 1994). In a detailed study of fish swimming mechanics, Boisclair \& Tang (1993) analysed simultaneous estimates of fish swimming behaviour and swimming cost for 10 species and concluded that energy expenditures associated with different swimming patterns were significantly different. Boisclair \& Tang (1993) demonstrated that 'routine' swimming (characterized by marked changes in swimming direction and speed) was a more expensive swimming pattern than 'directed' swimming (characterized by quasi-rectilinear movements executed at relatively constant swimming speed) and ascribed the increased energetic costs to increased swimming pattern complexity.

Similar results have been obtained from other studies. Forstner \& Wieser (1990) observed that a swimming pattern of high complexity was associated with higher metabolic costs than one of low complexity in roach Rutilus rutilis. Weatherley et al. (1982) and Puckett \& Dill (1984) demonstrated that unsteady motions were associated with substantial increases in energetic costs compared with steady swimming at the same average speed for rainbow trout Salmo gairdneri and coho salmon Oncorhynchus kisutch respectively. Webb (1991) attributed the elevated energetic costs of routine swimming (unsteady motions of linear and centripetal acceleration) in rainbow trout compared to steady swimming (relatively constant rectilinear speeds) to additional resistance components associated with acceleration.

There is, therefore, clear evidence that the energy expended by a swimming fish is not only dependent upon swimming speed, but is also strongly influenced by the complexity of the swimming pattern employed. The 'routine' and 'directed' swimming patterns of Boisclair \& Tang (1993) are comparable to swimming patterns displayed by pilchard during particulate-feeding and filter-feeding respectively. The increased metabolic costs associated with particulate-feeding are, therefore, a result of the higher complexity of this swimming pattern. 
An additional factor which may account for the relatively low cost of filter-feeding is the fact that pilchard swim in a tight school when filtering (van der Lingen 1994). When particulate-feeding, however, the fish do not school per se, but form a loose aggregation (or shoal sensu Pitcher 1979) within which they execute independent motions. In addition to reducing predation pressure and facilitating reproduction (Partridge 1982), schooling has also been suggested as a mechanism which confers a hydrodynamic advantage (Weihs 1973, Breder 1976). Each individual fish leaves a vortex trail that leads the fish which is/are following into a series of vortices at a point where water flow is in the direction the fish are swimming (Breder 1976). This results in the fish which follow(s) expending less energy than it/they would in the absence of schooling. However, this advantage only occurs when nearest neighbours are in diagonal positions in the lateral plane and the lateral distance between fish is less than 1 BL (Blaxter \& Hunter 1982). In the current study, school compaction in the lateral plane by filter-feeding pilchard was more conspicuous than it was in nonfeeding or particulate-feeding fish. Although no data on school structure were collected, lateral inter-fish distance during filter-feeding was certainly less than $1 \mathrm{BL}$. It is plausible, therefore, that formation of a compact school during filter-feeding bestows a hydrodynamic advantage upon the fish, hence reducing energy expenditure during this feeding mode. A schooling-derived hydrodynamic advantage resulting in reduced metabolic rates has also been postulated for American shad Alosa sapidissima (Ross et al. 1992).

This study has demonstrated that filter-feeding is energetically cheaper than particulate-feeding for Sardinops sagax. At slow swimming speeds, filterfeeding does not appear to increase metabolic costs significantly. Previous experimental work (van der Lingen 1994) has established that pilchard filter-feed upon a wide variety of food organisms, ranging from single phytoplankton cells through to macrozooplankton. Although pilchard is predominantly a filter-feeder, low concentrations of particles larger than $1230 \mu \mathrm{m}$ total length elicit a particulate-feeding response. These findings indicate that pilchard maximize their net energetic gain through prolonged bouts of low-cost filter-feeding. The feeding response flexibility of this species however, allows it to utilize large, scarce food organisms through particulate-feeding.

Acknowledgements. I thank Dr L. V. Shannon, Director of the Sea Fisheries Research Institute (SFRI), for funds and facilities for this research. I am grateful to E. J. Malan, M. Weilbach, A. Polito, A. du Randt, A. Kemp, R. Hudsonberg, D. Horstman and D. Calder for technical assistance. P. Monteiro and C.
Colima Melo performed the $\mathrm{CO}_{2}$ determinations. Drs G. C. Pitcher, M. J. Gibbons and L. Hutchings are warmly thanked for their comments on early drafts of the manuscript.

\section{LITERATURE CITED}

Armstrong MJ, Thomas RM (1989) Clupeoids. In: Payne AlL Crawford RJM (eds) Oceans of life off southern Africa Vlaeberg, Cape Town, p 105-121

Beamish FWH (1981) Swimming performance and metabolic rate of three tropical fishes in relation to temperature Hydrobiologia 83:245-254

Beamish FWH (1990) Swimming metabolism and temperature in juvenile walleye, Stizostedion vitreum vitreum. Environ Biol Fish 27:309-314

Blaxter JHS, Hunter JR (1982) The biology of the clupeoid fishes. Adv mar Biol 20:1-223

Boisclair D, Tang M (1993) Empirical analysis of the influence of swimming pattern on the net energetic cost of swimming in fishes. J Fish Biol 42:169-183

Breder CM (1976) Fish schools as operational structures. Fish Bull US 74:471-502

Brett JR (1964) The respiratory metabolism and swimming performance of young sockeye salmon. J Fish Res Bd Can 21:1183-1226

Brett JR (1965) The relation of size to rate of oxygen consumption and sustained swimming speed of sockeye salmon (Oncorhynchus nerka). J Fish Res Bd Can 22: $1491-1501$

Brett JR, Groves TDD (1979) Physiological energetics. In Hoar WS, Randall DJ, Brett JR (eds) Fish physiology, Vol VIIl, Energetics and growth. Academic Press, New York, p 279-352

Brett JR, Sutherland DB (1965) Respiratory metabolism of pumpkinseed (Lepomis gibbosus) in relation to swimming speed. J Fish Res Bd Can 22:405-409

Crawford RJM (1987) Food and population variability in five regions supporting large stocks of anchovy, sardine and horse mackerel. In: Payne AIL, Gulland JA, Brink KH (eds) The Benguela and comparable ecosystems. S Afr J mar Sci 5:735-757

Crawford RJM, Shannon LV, Pollock DE (1987) The Benguela ecosystem. Part IV The major fish and invertebrate resources. Oceanogr mar Biol A Rev 25:353-505

Culberson $\mathrm{CH}$ (1981) Direct potentiometry. In: Whitfield M, Jagner $D$ (eds) Marine electrochemistry. John Wiley, Chichester, p 187-262

Davies DH (1957) The South African pilchard (Sardinops ocellatal. Preliminary report on feeding of the west coast, 1953-56. Investl Rep Div Fish Un S Afr 30:1-40

Drenner RW, deNoyelles F Jr, Kettle D (1982) Selective impact of filter-feeding gizzard shad on zooplankton community structure. Limnol Oceanogr 27:965-968

Durbin AG, Durbin EG (1975) Grazing rates of the Atlantic menhaden Brevoortia tyrannus as a function of particle size and concentration. Mar Biol 33:265-277

Durbin AG, Durbin EG, Verity PG, Smayda TJ (1981) Voluntary swimming speeds and respiration rates of a filterfeeding planktivore, the Atlantic menhaden, Brevoortia tyrannus (Pisces: Clupeidae). Fish Bull US 78(4):877-886

Forstner H, Wieser W (1990) Patterns of routine swimming and metabolic rate in juvenile cyprinids at three temperatures: analysis with a respirometer-activity-monitoring system. J comp Physiol B 160:71-76

Fry FEJ (1971) The effect of environmental factors on the physiology of fish. In: Hoar WS, Randall DJ (eds) Fish 
physiology, Vol VI, Environmental relations and behaviour. Academic Press, New York, p 1-98

Hettler WF (1976) Influence of temperature and salinity on routine metabolic rate and growth of young Atlantic menhaden. J Fish Biol 8:55-65

Jagner D (1981) Potentiometric titrations. In: Whitfield M, Jagner D (eds) Marine electrochemistry. John Wiley, Chichester, p 263-300

James AG (1987) Feeding ecology, diet and field based studies on feeding selectivity of the Cape anchovy Engraulis capensis Gilchrist. S Afr J mar Sci 5:673-692

James AG (1988) Are clupeoid microphagists herbivorous or omnivorous? A review of the diets of some commercially important clupeoids. S Afr J mar Sci 7:161-177

James AG, Findlay KP (1989) Effect of particle size and concentration on feeding behaviour, selectivity and rates of food ingestion by the Cape anchovy Engraulis capensis. Mar Ecol Prog Ser 50:275-294

James AG, Probyn T (1989) The relationship between respiration rate, swimming speed and feeding behaviour in the Cape anchovy Engraulis capensis Gilchrist. J exp mar Biol Ecol 131:81-100

James AG, Probyn T, Hutchings L (1989a) Laboratory-derived carbon and nitrogen budgets for the omnivorous planktivore Engraulis capensis Gilchrist. J exp mar Biol Ecol 131: $124-145$

James AG, Probyn T, Seiderer LJ (1989b) Nitrogen excretion and absorption efficiencies of the Cape anchovy Engraulis capensis Gilchrist fed upon a variety of plankton diets. J exp mar Biol Ecol 131:101-124

Janssen J (1976) Feeding modes and prey size selection in the alewife (Alosa pseudoharengus). J Fish Res Bd Can 33: $1972-1975$

Johnstone ADF, Wardle CS. Almatar SM (1993) Routine respiration rates of Atlantic mackerel, Scomber scombrus L., and herring, Clupea harengus L., at low activity levels. J Fish Biol 42:149-151

King DPF, Macleod PR (1976) Comparison of the food and filtering mechanism of pilchard Sardinops ocellata and anchovy Engraulis capensis off South West Africa, 1971-1972. Investl Rep Sea Fish Brch S Afr 111: $1-29$

Kutty MN (1968) Respiratory quotients in goldfish and rainbow trout. J Fish Res Bd Can 25:1689-1728

Lasker R (1970) Utilisation of zooplankton energy by a Pacific sardine population in the California Current. In: Steele $\mathrm{JH}$ (ed) Marine food chains. Oliver and Boyd, Edinburgh, p 265-284

Lluch-Belda D, Crawford RJM, Kawasaki T, MacCall AD, Parrish RH, Schwartzlose RA, Smith PE (1989) World-wide fluctuations in sardine and anchovy stocks: the regime problem. S Afr J mar Sci 8:195-205

Lluch-Belda D, Schwartzlose RA, Serra R, Parrish R, Kawasaki T, Hedgecock D, Crawford RJM (1992) Sardine and anchovy regime fluctuations of abundance in four regions of the world oceans: a workshop report. Fish Oceanogr 1 . 339-347

Muir BS, Niimi AJ (1972) Oxygen consumption of the euryhaline fish aholehole (Kuhlia sandvicensis) with reference to salinity, swimming, and food consumption. J Fish Res Bd Can 29:67-77

Oudot C, Gerard R, Morin P, Gningue I (1988) Precise shipboard determination of dissolved oxygen (Winkler proce-

This article was submitted to the editor dure) for productivity studies with a commercial system. Limnol Oceanogr 33:146-150

Parrish RH, Bakun A, Husby DM, Nelson CS (1983) Comparative climatology of selected environmental processes in relation to eastern boundary current pelagic fish reproduction. In: Sharp GD, Csirke J (eds) Proceedings of the expert consultation to examine changes in abundance and species composition of neritic fish resources, San José, Costa Rica. FAO Fish Rep 291(3):731-777

Parrish RH, Serra R, Grant WS (1989) The monotypic sardines, Sardina and Sardinops: their taxonomy, distribution, stock structure and zoogeography. Can J Fish Aquat Sci 46:2019-2036

Partridge BL (1982) The structure and function of fish schools. Scient Am 246:90-99

Peterson WT, Hutchings L, Huggett JA, Largier JL (1992) Anchovy spawning in relation to the biomass and the replenishment rate of their copepod prey on the western Agulhas Bank. In: Payne AlL, Brink KH, Mann KH, Hilborn R (eds) Benguela trophic functioning. S Afr J mar Sci 12:487-500

Pitcher $T$ (1979) Sensory information and the organisation of behaviour in a shoaling cyprinid fish. Anim Behav 27: $126-149$

Puckett KJ, Dill LM (1984) Cost of sustained and burst swimming in juvenile coho salmon (Oncorhynchus kisutch). Can J Fish Aquat Sci 41:1546-1551

Ross RM, Backman TWH, Limburg KE (1992) Group-sizemediated metabolic rate reduction in American shad. Trans Am Fish Soc 121:385-390

Schmidt-Nielsen K (1982) Animal physiology: adaptation and environment, 2nd edn. Cambridge University Press, Cambridge

Shelton PA, Hutchings L. (1990) Ocean stability and anchovy spawning in the southern Benguela Current system. Fish Bull US 88:323-338

Talbot MMJF, Baird D (1985) Oxygen consumption of the estuarine round herring Gilchristella aestuarius (Gilchrist \& Thompson). S Afr J Zool 20:1-4

van der Lingen CD (1994) Effect of particle size and concentration on the feeding behaviour of adult pilchard Sardinops sagax. Mar Ecol Prog Ser 109:1-13

Videler JJ (1993) Fish swimming. Chapman \& Hall, London

Wallace-Fincham BP (1987) The food and feeding of Etrumeus whiteheadi Wongratana 1983, off the Cape Province of South Africa. MSc thesis, University of Cape Town

Weatherley AH, Rogers SC, Pinock DG, Patch JR (1982) Oxygen consumption of active rainbow trout, Salmo gairdneri Richardson, derived from electromyograms obtained by radiotelemetry. J Fish Biol 20:479-489

Webb PW (1975) Hydrodynamics and energetics of fish propulsion. Bull Fish Res Bd Can 190:1-158

Webb PW (1991) Composition and mechanics of routine swimming of rainbow trout, Oncorhynchus mykiss. Can J Fish Aquat Sci 48:583-590

Weihs D (1973) Hydrodynamics of fish schooling. Nature 241: 290-291

Willıams PJLeB, Jenkinson NW (1982) A transportable microprocessor-controlled precise Winkler titration suitable for field station and shipboard use. Limnol Oceanogr 27 $576-585$

Zar JH (1984) Biostatistical analysis, 2nd edn. Prentice-Hall Englewood Cliffs, NJ

Manuscript first received: February 27, 1995

Revised version accepted: May 29, 1995 